\title{
Testicular Recovery Effects of Folinic Acid on Cyclophosphamide Induced Damage in Rat
}

\author{
Afsan $\mathrm{M}^{1}$, Ahmed $\mathrm{AHH}^{2}$, Khaleque $\mathrm{MA}^{3}$, Nessa $\mathrm{J}^{4}$
}

\begin{abstract}
Background: Cyclophosphamide is a cytotoxic drug and used as anti-neoplastic agent. It produces gonadal damage leading to infertility. On the other hand Folinic acid is essential in purine synthesis, prevents DNA beak down and essential for spermatogenesis. Therefore, the present study was designed to observe the recovery role of Folinic acid on Cyclophosphamide induced testicular damage. Objective: To observe the recovery effects of Folinic acid on Cyclophosphamide induced testicular damage in Long Evans rats. Methodology: This experimental study was carried out from July 1998 to June 1999 in the Department of Pharmacology, IPGM \& R (Under Dhaka University) Dhaka. Twenty four adult Long Evans male rats were pre-treated with Cyclophosphamide, then divided into two groups (A and B).Group of no drug was compared with Folinic acid treated group in 14 day and 28 days. Cytotoxic damage and recovery was assessed by measuring of body weight, testicular weight and volume and the histological findings likely- number of seminiferous tubules, spermatozoa containing tubules, and mean diameter of seminiferous tubules per microscopic field (10X). Serum Testosterone was estimated by Radio Immunoassay to assess if there any Leydig cell damage of rat testes during Cyclophosphamide treatment. Results: After Cyclophosphamide induced toxicity, treatment with Folinic acid produced significant increased in the histological parameters likely- number of seminiferous tubules, spermatozoa containing tubules and mean diameter of seminiferous tubules in 14 days $(\mathrm{p}<0.001)$ and 28 days $(\mathrm{p}<0.05)$. Conclusion: Folinic acid provides significant recovery effects after cyclophosphamide induced gonadal damage in Long Evans rats.
\end{abstract}

Key words : cyclophosphamide, folinic acid, testicular damage

\section{Introduction}

Infertility or sterility is an absolute state of inability to conceive $^{1}$. It is a global problem ${ }^{2}$. Distribution of all causes of infertility between two sexes shows a female cause in $55.7 \%$ and a male cause in $44.3 \% \%^{3,4}$. The inability to bear a child is a tragedy for many couples, bringing a sense of loss, failure and exclusion ${ }^{5}$.

Among all cases of infertility in developed countries, about $8 \%$ can be traced to male factors, $37 \%$ can be due to female factors, and $35 \%$ can be due to factors in both the male and female partners 5 . In about $5 \%$ percent of couples, the cause of the infertility cannot be traced to specific factors in either partner ${ }^{4}$. About $90 \%$ of male infertility is caused by hypogonadism resulting in impaired spermatogenesis; and $80 \%$ to $90 \%$ percent of these men have isolated deficiency of sperm production with normal androgen production of unclear aetiology known as idiopathic oligospermia or azoospermia ${ }^{6}$. The morphological abnormalities include mostly appearance of immature cells like spermatids and spermatocytes these are the cells of previous lineage of spermatogenesis prior to spermatozoa $^{7}$. These abnormalities are due to various causes like infection, trauma, other testicular stress, certain drugs, or normal imbalance. Also tapered head sperm and immature sperm precursors are frequently associated with conditions such as varicocele, as well as viral and bacterial infection $^{8}$. Allergic reaction causes a characteristic increases in amorphous and immature sperm cell and less in tapered form ${ }^{9}$. The presence of many round cells in seminal fluid is not always related to evident testicular (varicocele, hydrocele, flogosis) or systemic (infection, hepatic, renal, hormonal) disease. These patients are said to be affected by round cell idiopathic syndrome ${ }^{5}$. During anticancer therapy with cyclophosphamide on male, similar to the feature of immature ejaculate syndrome appears ${ }^{10}$. Treatment with cyclophosphamide leads to azoospermia and disappearance of germinal epithelium with preservation of sertoli cells ${ }^{9}$. So, cyclophosphamide acts as gonadotoxin in human and laboratory animal ${ }^{10}$. The aim of medical therapy in infertile male is the improvement or normalization of the fertility status of the sub-fertile individual in order to increase the chance of a pregnancy within a given time. Administration of various

1. Dr. Md. Afsan, Associate Professor \& Head, Department of Pharmacology and Therapeutics, East West Medical College, Uttara, Dhaka

2. Dr. A. H. Hamid Ahmed, Assistant Professor, Department of Nephrology, Bangabandhu Sheik Mujib Medical University, Shahbagh, Dhaka

3. Dr. Md. Abdul Khalegue, Associate Professor, Department of Opthalmology, Bangabandhu Sheik Mujib Medical University, Shahbagh, Dhaka

4. Dr. Jebun Nessa, Assistant Professor, Department of Physical Medicine, Shaheed Suhrawardy Medical College, Sher-E-Bangla Nagar, Dhaka

\section{Correspondence}

Dr. Md. Afsan, Associate Professor \& Head, Department of Pharmacology and Therapeutics, East West Medical College, Khayertek, Turag, Uttara, Dhaka-1711; Email: mafsan@ yahoo.com; Mobile : 01712152360 
vitamins to improve fertility was tried to increase spermatogenesis. Folinic acid is usually employed in the therapy of various folate deficiencies and as an antidote during antimetabolites therapy. This agent probably essential to the maturation for rapidly developing cells likely spermatozoa ${ }^{10,11}$. Folinic acid therapy in 65 sterile males showed significant increase in spermatozoa number, motility, and decrease in round cell amount ${ }^{11}$. With these considerations in mind, the present study was designed to observe the recovery effects of folinic acid against cyclophosphamide induced sterility in an animal model.

\section{Methodology}

The study was carried out on twenty four healthy adult male rats of long Evans Norwegian strain of average weight 210 gm. Body weight in the Department of Pharmacology at Bangabandhu Sheikh Mujib Medical University (BSMMU) Dhaka, Bangladesh for 42 days. Animals were housed in standard condition and allowed food and water and libitum. They were grouped into two. Cyclophosphamide in a dose of $50 \mathrm{mg} / \mathrm{kg}$ /day intraperitoneally was given in every alternative day for 14 days $^{11}$ and folinic acid in a dose of 6 $\mathrm{mg}$ tablet dissolved in $500 \mathrm{ml}$ dextrose in aqua was given orally $^{11}$. At the end of experiment-I at $28^{\text {th }}$ day, and experiment-II at $42^{\text {nd }}$ day, the rats were weighed and sacrificed. The testes were collected for measuring weight, volume and histological examination. Blood was collected for serum testosterone measurement by Radio Immunoassay in Nuclear Medicine Institute at BSMMU. The testis was fixed in $10 \%$ formal solution, washed in tap water, dehydrated in alcohol, cleaned in xylene and embedded in melted paraffin. Serial sections of 5 micron thickness of testicular tissue were made and stained with Haematoxylin and Eosin (H\&E) Stain. Mean values and standard errors were calculated for the number of seminiferous tubule, tubular diameter, spermatozoa containing tubules per microscopic field. For statistic analysis, Student's t ' test was used to compare the results in the experimental groups.

\section{Results}

The effects of Cyclophosphamide for 14 days then no drug (Group-A) and treatment with Folinic acid (Group-B) on body weight, testicular weight, volume and histology after 14 days and 28 days in rats is shown in Table 1 and 2.

Serum testosterone level in all groups was shown in Table 3. After 14 and 28 days of Folinic acid therapy, there was significant improvement in histological parameters likelyincreased number of seminiferous tubules, percentage of spermatozoa containing tubules, diameter of seminiferous tubule than non drug intervention group. Statistically it was significant. There was no significant difference in gross physical parameters and serum testosterone level in between the Folic acid treated group and spontaneous recovery group.

\section{Discussion}

The dose and duration of cyclophosphamide and folinic acid treatment in the rats were selected from previous observations $^{11}$. In the present study, Cyclophosphamide was treated for 14 days to ensure damage of all dividing germinal cell in a cycle of seminiferous epithelium ${ }^{12}$.

Table 1: Showing Rat body weight, Testis weight and testis volume in different groups

\begin{tabular}{|c|c|c|c|c|c|c|c|}
\hline \multirow{2}{*}{ Experiment } & \multirow{2}{*}{$\begin{array}{l}\text { Rat } \\
\text { Group } \\
\mathbf{N}=6\end{array}$} & \multicolumn{2}{|c|}{ Rat Body Weight (Gm) } & \multicolumn{3}{|c|}{ Rat Testes Weight (Gm) } & \multirow[b]{2}{*}{$\begin{array}{c}\text { Testes } \\
\text { Volume } \\
(\mathrm{ml}) \\
\text { Mean } \pm \text { SEM }\end{array}$} \\
\hline & & $\begin{array}{c}\text { Initial weight } \\
\text { Mean } \pm \text { SEM }\end{array}$ & $\begin{array}{c}\text { Final weight } \\
\text { Mean } \pm \text { SEM }\end{array}$ & $\begin{array}{c}\text { Change of } \\
\text { body weight } \\
\text { Mean } \pm \text { SEM }\end{array}$ & \begin{tabular}{l}
\multicolumn{1}{c}{ Testes } \\
weight $(\mathbf{m g})$ \\
Mean \pm SEM
\end{tabular} & $\begin{array}{l}\text { Testes weight } \\
\text { as gm } \% \text { of } \\
\text { body weight } \\
\text { Mean } \pm \text { SEM }\end{array}$ & \\
\hline \multirow{2}{*}{ I } & A & $211.66 \pm 4.49$ & $284.33 \pm 3.94$ & $34.58 \pm 3.03$ & $31.0 \pm 0.6$ & $1.08 \pm 0.01$ & $3.21 \pm 0.08$ \\
\hline & $\mathrm{B}$ & $212.5 \pm 5.28$ & $291.8 \pm 5.57$ & $\begin{array}{c}38.31 \pm 1.21 \\
\text { NS }\end{array}$ & $\begin{array}{c}31.4 \pm 0.6 \\
\text { NS }\end{array}$ & $\begin{array}{c}1.07 \pm 0.01 \\
\text { NS }\end{array}$ & $\begin{array}{c}3.25 \pm 0.07 \\
\text { NS }\end{array}$ \\
\hline \multirow{2}{*}{ II } & A & $217.5 \pm 6.55$ & $319.5 \pm 7.13$ & $47.76 \pm 2.64$ & $36.6 \pm 0.6$ & $1.14 \pm 0.02$ & $3.91 \pm 0.04$ \\
\hline & $\mathrm{B}$ & $215 \pm 5.16$ & $320.16 \pm 3.30$ & $\begin{array}{c}49.15 \pm 2.4 \\
\text { NS }\end{array}$ & $\begin{array}{c}36.8 \pm 0.3 \\
\text { NS }\end{array}$ & $\begin{array}{c}1.14 \pm 0.01 \\
\text { NS }\end{array}$ & $\begin{array}{c}3.95 \pm 0.07 \\
\text { NS }\end{array}$ \\
\hline
\end{tabular}

Group A: Cyclophosphamide for 14 days, then normal diet for 14 days (Experiment-I) and 28 days (Experiment-II); Group B: Cyclophosphamide for 14 days, then Folinic acid for 14 days (Experiment-I) and 28 days (Experiment-II) p- values $>0.05$; NS= not significant 
Table 2: Comparison of seminiferous tubular number with or without spermatozoa and diameter of seminiferous tubules between the groups

\begin{tabular}{|c|c|c|c|c|}
\hline Experiment & $\begin{array}{c}\text { Rat } \\
\text { Group } \\
n=6\end{array}$ & $\begin{array}{l}\text { Number of } \\
\text { seminiferous } \\
\text { tubules } \\
\text { Mean } \pm \text { SEM }\end{array}$ & $\begin{array}{l}\text { Spermatozoa } \\
\text { containing } \\
\text { seminiferous } \\
\text { tubules } \\
\text { Mean } \pm \text { SEM }\end{array}$ & $\begin{array}{c}\text { Diameter of } \\
\text { seminiferous } \\
\text { tubules }(\mu) \\
\text { Mean } \pm \text { SEM }\end{array}$ \\
\hline \multirow{2}{*}{ I } & A & $16.16 \pm 0.47$ & $14.31 \pm 1.92$ & $185.99 \pm 4.44$ \\
\hline & B & $22.83 \pm 1.13 * *$ & $48.02 \pm 2.89 * *$ & $241.54 \pm 4.83 * *$ \\
\hline \multirow{2}{*}{ II } & $\mathrm{A}$ & $19.83 \pm 0.60$ & $45.57 \pm 2.18$ & $260.86 \pm 8.36$ \\
\hline & B & $22.16 \pm 0.60 *$ & $55.7 \pm 2.66^{*}$ & $297.1 \pm 6.2^{*}$ \\
\hline
\end{tabular}

Group - A: Cyclophosphamide for 14 days, then normal diet for 14 days (Experiment-I) and 28 days (Experiment-II); Group - B: Cyclophosphamide for 14 days, then Folinic acid for 14 days (Experiment-I) and 28 days (Experiment-II); ${ }^{* * *} \mathrm{p}<0.001 ;{ }^{*} \mathrm{p}<0.05$

Cyclophosphamide was found to produce testicular damage in rats as evident by significant reduction of body weight, testicular weight \& volume, number of seminiferous tubules, number of spermatozoa containing tubules and mean tubular diameter. The result was consistent with the findings of other investigators who conducted similar types of study, ${ }^{9,10}$.

Table 3: Showing serum Testosterone level of different group of Rats

\begin{tabular}{cccc}
\hline Experiment & Group & $\begin{array}{c}\text { Serum } \\
\text { Testosterone } \\
\text { (nmol/L) } \\
\text { Mean } \pm \text { SEM }\end{array}$ & P value \\
\hline I & A(control) & $17.5 \pm 3.81$ & $\begin{array}{c}\text { Group I-A vs } \\
\text { Group I-B : } \\
\text { Not significant }\end{array}$ \\
II & B (control) & $35.83 \pm 7.12$ & $\begin{array}{c}\text { Group II-A vs } \\
\text { Group II-B : } \\
\text { Not significant }\end{array}$ \\
& B & $41.16 \pm 7.1^{N S}$ & NS \\
\end{tabular}

Group A: Cyclophosphamide for 14 days, then normal diet for 14 days (Experiment-I) and 28 days (Experiment-II); Group B: Cyclophosphamide for 14 days, then Folinic acid for 14 days (Experiment-I) and 28 days (Experiment-II)

Cyclophosphamide has the property of becoming strong electrophiles to target molecules of nucleus of dividing cells. This reaction result in the formation of covalent linkage by alkylation of various nucleofilic moieties such as phosphate, amino, sulfhydryl, carboxyl, and imidazole groups in $\mathrm{DNA}^{13}$. In the present study folinic acid treatment showed significant gonadal recovery effect in cyclophosphamide induced cytotoxicity. The possible role of folinic acid in recovery of testicular damage could be due to effect on mammalian DNA synthesis ${ }^{14,15,16,17}$. As folate cofactors are essential for one carbon transfer reaction involved in de novo synthesis of the purine heterocycles. Inhibition of synthesis of thymidylic acid (2-deoxythymidine monophosphate-dTMP), an essential precursor of DNA, is also suggested ${ }^{16}$. Folates also prevent uracil incorporation into human DNA and thus prevent DNA breakage ${ }^{17}$.

\section{Conclusion}

In the present study, cyclophosphamide had no significant effects on steroidogenesis, as the present cytotoxic dose might have no toxic effects on Leydig cell. The study suggests that folinic acid has got some recovery role in cyclophosphamide induced testicular damage of rat. Further study in human regarding its dose, duration of treatment and determination of margin of safety should be carried out.

\section{References}

1. Gabaldon A, Mofid C, Morishta K, Moskovski S, Sankale M, Standen 1. Guzick DS. Evaluation of the infertile couple. Updated on: June 12, 2010; Accessed on December 15, 2011 [Web Site: http://www.uptodate.com/home/index.html]

2. Cooper TG, Noonan E, von Eckardstein S et al. World Health Organization reference values for human semen characteristics. Hum Reprod Update 2010;16(3):231-45

3. Cavallini G. Male idiopathic oligoasthenoteratozoospermia. Asian J Androl 2006;8(2):143-157

4. Hirsh A. Male sub-fertility. BMJ 2003;327(7416):669-72

5. Swerdloff RS, et al. Causes of male infertility. Updated on: June 12, 2010; Accessed on December 15, 2011 [Web site: http://www.uptodate.com/home/index.html] 6. WHO, 14th Annual report. septial program of research, development and research training in Human reproduction,Geneva,December1985

7. Macleod J. Human seminal cytology as a sensitive indicator of the germinal epithelium. International Journal of Fertility 1964;9:281-95

8. Shalet SM. Effect of cancer chemotherapy on Gonadal function of patients. Cancer treatment Reviews 1980;7:141-52

9. Etterdorft JN, West CD, Pitcock JA, Williams DL. Gonadal function, Testicular histology and meiosis following cyclophosphamide therapy in patient with nephrotic. The Journal of Paediatrics 1976;88:206-12

10. Blumfeld Z, Haim N. Prevention of Gonadal damage during cytotoxic therapy .The Finish Medical Society. Ann Med 1997;29:199-20

11. Bentivoglio G, Melica F, Cristoforoni P. Folic acid in the treatment of Human male infertility and sterility 1993;60(4):698-701

12. Clermont Y. Kinetics of spermatogenesis in mammals: seminiferous epithelium cycle and spermatogonial renewal. Physiological Reviews 1972;52(1):198-235

13. Edward C, Alan SC. Cancer Chemotherapy. In: Katgung BG, editor. Basic \& Clinical Pharmacology. 11th ed. Tata McGraw-Hill edition2009; p.882-85 14. Krumdieck CL, Boots LR, Cornwell PE and Butterworth CE. Cyclic variations in folate composition and pteroylpolygluamyl hydrolase (conjugate) activity of rat uterus. The American Journal of Clinical Nutrition 1976;29(3):288-94

15. Butterworth CE, Hatch KD, Gore H, Mueller H, Krumdieck CL. Improvement of cervical dysplasia associated with folic acid therapy in user of oral contraceptives. The American Journal of Clinical Nutrition 1982;35:73-82 16. Susan MB. Agents used in anaemia; Hematopoietic growth factors, in chapter 33, In: Katgung BG, editor. Basic and clinical Pharmacology. 11th ed. India: Tata McGraw-Hill edition 2009; p.534-36 
17. Ames BN. Micronutrients Prevent Cancerand delay aging.Toxicol Left. 1998;28:102-3

18. Hooreg JJG, van de Delemae W et al. Cyclophosphamide induced disturbance of Gonadotropin secretion manifesting testicular damage. Acta Endocrinologica 1992; 126: 143-48 